\title{
Future Platforms for Copyright Licensing
}

\author{
Paul Goldstein
}

Published online: 4 March 2015

(C) Max Planck Institute for Innovation and Competition, Munich 2015

The founding economic premise behind copyright and author's right is that the grant of exclusive property rights will best promote the creation of literary and artistic works. Behind this economic premise lies another: that by making these exclusive rights transferable, the legislator can ensure the widest possible dissemination of these works, and consequently the greatest public benefit. Of course, the fact that a right is transferable is no guarantee that a license or other transfer will occur, even among otherwise willing parties, for in a great many circumstances transaction costs - the costs of identifying and negotiating with the right owner - will defeat the transaction.

A common legislative response to situations where the game is not worth the candle - where the value of a use characteristically falls below the transaction costs of concluding a license for it - has been to excuse the use through statutory limitations or defenses or, as a half-way measure, to subject the use to a compulsory license. But the greatest mistake a legislator can make about transaction costs is to assume that they are immutable, and to carve out limitations or statutory licenses in the belief that private arrangements cannot be designed that will resolve the transaction costs problem. The great lesson of the collecting rights organizations, starting in late eighteenth-century France with the organization that ultimately evolved into the Société des Auteurs et Compositeurs Dramatiques, has been that institutional - and eventually technological - innovations can reduce transaction costs to levels at which revenues can be returned to creators where previously they could not.

The digital revolution, although it has vastly expanded the circumstances in which transaction costs may be thought to overwhelm the value of private, individualized uses of copyrighted works, in fact offers substantial opportunities to

P. Goldstein $(\bowtie)$

Professor of Law

Stanford Law School, Stanford University, Stanford, USA

e-mail: paulgold@stanford.edu 
reduce, virtually to the cost of electricity, the transaction costs associated with these widely dispersed uses, thus making it possible for revenues to be returned to creators with a degree of perfection unavailable even to the collecting societies. Blanket licenses of the sort made possible by collecting societies will no doubt continue to exist, but we can also expect per-use licenses - often only for micro-payments - to proliferate alongside them.

Digital licensing services are just now beginning to emerge. SIPX, a for-profit spinoff of a Stanford University-based research project, today provides seamless, automated one-stop shopping for instructors assembling copyright-compliant course readings, and includes public domain and open-access content free of charge. Although still in its early stages, the Copyright Hub in Britain offers a preview of what a more encompassing digital transaction platform might look like. With support from the British Government and matching funds from the copyright industries, the Copyright Hub proposes to evolve into a working implementation that will match the needs of owners and users over a broad terrain of copyrighted content. By reducing transaction costs, one of the Hub's central goals is to enable a simpler licensing process for high volumes of low-value activity.

During the current academic year, a group of Stanford University law, business and computer science students has been working in an academic partnership with the United States Copyright Office to take the initial steps toward developing a digital licensing platform for photographic images that will enable not only frictionless transactions between photographers and users, but also ongoing management of the uses made under each digital license.

In time, more platforms will emerge to bridge the existing transactional gaps between creators and users, thus reducing the need for such temporizing solutions as statutory limitations and compulsory licenses. The responsibility of the legislator will be to foster, not hinder, such developments in order to reform copyright law around its founding economic premise. 